The Likeness 
ETHNOGRAPHIC STUDIES IN SUBJECTIVITY

Tanya Luhrmann, Editor

1. Forget Colonialism?: Sacrifice and the Art of Memory in Madagascar, by Jennifer Cole

2. Sensory Biographies: Lives and Deaths among Nepal's Yolmo Buddhists, by Robert Desjarlais

3. Culture and the Senses: Bodily Ways of Knowing in an African Community, by Kathryn Linn Geurts

4. Becoming Sinners: Christianity and Moral Torment in a Papua New Guinea Society, by Joel Robbins

5. Jesus in Our Wombs: Embodying Modernity in a Mexican Convent, by Rebecca J. Lester

6. The Too-Good Wife: Alcohol, Codependency, and the Politics of Nurturance in Postwar Japan, by Amy Borovoy

7. Subjectivity: Ethnographic Investigations, edited by João Biehl, Byron Good, and Arthur Kleinman

8. Postcolonial Disorders, edited by Mary-Jo DelVecchio Good, Sandra Teresa Hyde, Sarah Pinto, and Byron J. Good

9. Under a Watchful Eye: Self, Power, and Intimacy in Amazonia, by Harry Walker

10. Unsettled: Denial and Belonging Among White Kenyans, by Janet McIntosh

11. Our Most Troubling Madness: Case Studies in Schizophrenia across Cultures, by T.M. Luhrmann and Jocelyn Marrow

12. Us, Relatives: Scaling and Plural Life in a Forager World, by Nurit Bird-David

13. The Likeness: Semblance and Self in Slovene Society, by Gretchen Bakke 


\section{The Likeness}

SEMBLANCE AND SELF

IN SLOVENE SOCIETY

\section{Gretchen Bakke}

뚜

UNIVERSITY OF CALIFORNIA PRESS 
University of California Press

Oakland, California

(C) 2020 by Gretchen Bakke

Cataloging-in-Publication Data is on file at the Library of Congress.

ISBN 9780520320031 (cloth : alk. paper)

ISBN 9780520320048 (pbk. : alk. paper)

ISBN 9780520974173 (ebook)

Manufactured in the United States of America

$\begin{array}{llllllllll}29 & 28 & 27 & 26 & 25 & 24 & 23 & 22 & 21 & 20\end{array}$

$\begin{array}{llllllllll}10 & 9 & 8 & 7 & 6 & 5 & 4 & 3 & 2 & 1\end{array}$ 
With thanks, to Georges Bataille 
Time and again for more than two millennia the people we call "Western" have been haunted by the specter of their own inner being: an apparition of human nature so avaricious and contentious that, unless it is somehow governed it will reduce society to anarchy.

Marshall Sahlins, 2008

Couples are wholes and not wholes, what agrees disagrees, the concordant is discordant

Heraclitus, -535 (give or take) 